\title{
Descriptive Study of COVID-19 Outbreak, Clinical Assess- ment, and Psychological Impact on Saudi Residents in Wuhan, China
}

\author{
Afnan A. AlMAss ${ }^{* 1}$, Osamah M. Alshahrani ${ }^{2}$, Alhanouf F. Altamimi ${ }^{2}$, Omar A. Alghamdi ${ }^{2}$, Kholoud \\ A Alshiha ${ }^{2}$ and Saud A. Alghamdi ${ }^{2}$ \\ ${ }^{1}$ AdDariyah Hospital, Ministery of Health, Riyadh Saudi Arabia \\ ${ }^{2}$ Imam University, College of Medicine, Riyadh Saudi Arabia
}

*Corresponding author: Afnan A. AlMAss, Emergency Medicine Department, King Saud University Medical City, King Saud University, Riyadh 11321, Saudi Arabia.

To Cite This Article: Afnan A. AlMAss, Abdulaziz A. AlRabiah, Osamah M. Alshahrani, Alhanouf F. Altamimi, Omar A. Alghamdi, et al., Descriptive Study of COVID-19 Outbreak, Clinical Assessment, and Psychological Impact on Saudi Residents in Wuhan, China. 2020 - 10(5). AJBSR.MS.ID.001550. DOI: 10.34297/AJBSR.2020.10.001550.

Received: 畊 October 19, 2020; Published: 眥 October 27, 2020

\begin{abstract}
Background: The first cases of novel coronavirus outbreak (2019-nCoV) were the reason for a respiratory illness infection identified in Wuhan, China, in December 2019 and to date.

Objectives: The aim of this study is to follow up the clinical progress of the first group of Saudi students who came back from Wuhan, China on February 2nd, 2020 throughout the period of stay in quarantine. And identify the psychological effect of the widespread of 2019-nCoV while they were in Wuhan and the effect of fourteen days of quarantine.

Study design: A case descriptive study.

Methods: A total of 10 Saudi males who were evacuated by royal order from Wuhan city, China in February 2020 were enrolled in this study throughout 14 days of a continuous assessment while in quarantine. The assessment included the vital signs, associated symptoms, chronic diseases, and psychological state.

Results: In daily clinical assessment of the vital signs and other lab tests, data shows that the ten patients through 14 days were well and healthy. According to the pathology report of the sputum sample all came out to be negative twice. The psychosocial assessment was done and the effect of the quarantine was obvious on them, and they were anxious and fearful in the first couple of days and then started expressing feelings about how they miss their families and their need of joining up with their families as soon as possible. The last days of quarantine they developed some bouts of anger, restlessness, and irritability waiting for the discharge.

Conclusion: The psychological impact of the COVID-19 outbreak was humongous and affecting many populations. It is a worldwide dilemma these days. Mental health is crucial for all age groups and providing support for the population to help them bear these situations which require strict instructions that may change their lifestyle suddenly is critically important. We suggest engaging in regular physical activities, keeping and creating routines that give the sense of achievement and self-satisfaction during quarantine, will help in maintaining good mental health and in the meanwhile preventing Coronavirus disease (COVID-19) outbreak.
\end{abstract}

Keywords: Coronavirus disease COVID-19 (2019-nCoV), Saudi Arabia, Psychological impact, Wuhan city

\section{Introduction}

Coronaviruses (Coronaviridae family, Coronaviridae subfamily) are important pathogens that affect birds and mammals both Coronaviruses are viruses with a positive sense of RNA and are currently identified into four groups: Alphacoronavirus, Betacoronavirus, Gamma Coronavirus and Deltacoronavirus [1].
Coronaviruses are a large family of viruses that infect human beings which can cause illness beginning from common cold to more severe diseases such as the Middle East Respiratory Syndrome and Severe Acute Respiratory Syndrome [2]. It has been estimated that most coronaviruses are found to be hosted in Bats, which showed 
an alarming result that they have a role in the development and evolution of alpha and beta coronaviruses lineage. Nevertheless, other animals can serve as an intermediate host and wild animal reservoir [3]. Coronaviruses were identified in the 1960s when two viruses from the nasal cavities of human patients, so they were named human coronavirus 229E and human coronavirus OC43 [4]. New members of the same family were discovered later such as SARS-COV in 2003, HCoV NL63 in 2004, HKU1 in 2005, MERS$\mathrm{CoV}$ in 2012, and 2019n COV in 2019 [5]. The most aggressive and severe human coronaviruses are SARS-CoV that leads to Severe Acute Respiratory Syndrome (SARS) which is a fatal-lung disease in humans [6]. The detection of coronaviruses can be done through stool samples and this means that it can transmit from one to another [7]. Although Coronaviruses can easily be detected, there are no antiviral drugs to treat this infection until now [8].

\section{The 2019n Coronavirus}

In December 2019, a new strain of the coronaviruses' family outbroke in Wuhan, China; it is called the 2019n CoV [9]. There is an association between the Huanan Seafood market in Wuhan, China, which sells wild animals [10]. However, there are cases who confirmed to have the infection reported no contact with the market which raises two possibilities. The first one is that it is transmitted from human to another human, while the second is that the virus exists in more widespread animal source[11] It was found that the 2019-nCoV is most closely related to two severe acute respiratory syndrome (SARS)-like A CoV sequences that were isolated in bats throughout 2015 and 2017 [12]. The incubation period was found to be 4 days, and the period of stay in hospital was 12 days approximately [13]. Most of the studies assure that the main symptoms of the $2019 \mathrm{n} \mathrm{CoV}$ are fever or cough, shortage of breath, a headache, muscle ache, chest pain, diarrhoea, and fatigue $[14,15]$. A recent study has examined the clinical features of patients diagnosed with 2019 novel Coronavirus in Wuhan, China, the results have shown that the chest CT of all patients show that all the patients have pneumonia along with abnormal chest results [16].

As of this writing, This fatal disease caused 62,784 confirmed deaths, China had 3,304 deaths, while outside of China there were 59,480 deaths from 204 different countries and more than $1,133,758$ infected with COVID-19 since the outbreak of the corona pneumonia in December 2019 [17]. The case-fatality rate (CFR) appears to be increased in symptomatic patients. Nevertheless, patients who are slightly asymptomatic or symptomatic are considered, the CFR is most likely to be decreased over all [18]. The source of the virus is still unknown. Most of the studies agree that the virus has a $96 \%$ match to a bat coronavirus therefore, bats may be the main source of the virus [19]. However, there are suggestions that the virus originates in snakes [20]. The data of the new virus are limited.

A descriptive study done in Wuhan, found that $45 \%$ of the total 99 patients have admitted their direct exposure to the Human seafood market [21]. Even, some patients had earlier exposure to the seafood market for long periods such as salesmen and market managers [21]. Another study has found an epidemiological link between cases of Coronavirus and the Huanan Seafood Wholesale Market in Wuhan, Hubei Province where live animals were sold as well in 41 cases [22]. This study finds that most of the cases were men whose average age was 55.5 years [21,22]. Also, the study reveals that $51 \%$ of the cases had chronic diseases such as cardiovascular and cerebrovascular, endocrine, digestive system, and respiratory diseases [21,22]. Furthermore, a study conducted by Michelle Holshue, examined the appearance of the first case of the 2019 novel Coronavirus in the United States. The study affirms the hypothesis of the previous studies that there is a link between the 2019 novel Coronavirus and the Huanan Seafood Wholesale Market in Wuhan [21-23]. The study stresses that there is a person-to-person transmission of the infection [23]. As of now, the transmission speed of the infection is still unknown. [24].

The appropriate procedures in dealing with such an infection include isolation of patients who are proved to be infected with the Coronavirus [22]. Some studies investigated four lower respiratory tract samples. The laboratory analysis of the cases shows that the 2019n COV belongs to the genus beta coronavirus which involves other viruses such as SARS. This type exists in humans, bats, and other wild animals. The detection of the virus was a result of initial propagation of human respiratory secretion onto human airway epithelial cell cultures [25]. Another study has examined nine patients who were confirmed to have pneumonia, The results show that genome sequencing of the 2019n CoV released from the nine samples were identical with more than $99.98 \%$ identity with twobat originated severe acute respiratory syndrome (SARS): bat SLCoVZC45 and bat -SL-CoVZXC21 [26]. A research done by Daniel Chu has found that established essays can help detect the 2019n CoV accurately thereby helping to identify the virus among patients [27]. It was discovered by Liangsheng Zhang that mammals are the main source of the virus [12]. The leucocyte analysis of 99 samples of patients who are confirmed to have the virus show that $9 \%$ of patients were under normal range while $24 \%$ of patients were above the normal average. $75 \%$ of the patients indicate bilateral pneumonia [21].

So far, there is no recommended treatment available, it is advised to follow the MERS-CoV guideline treatment [13].

Our study objectives are: To identify the psychological effect of the disease has had on the people first trapped in Wuhan city and how the evacuation to Saudi Arabia affected them and how 
they coped with and the quarantine effect. And assessing the vitals alongside the symptoms of the patients to check their progress while monitoring the participants throughout the period of stay in quarantine.

We expect that the students who came from Wuhan will have the virus symptoms and If we monitor the patients daily, we can detect the exact signs and symptoms of the disease. we as well, expect to find them in an unpleasant psychological state.

However, there is still a need for a further epidemiological investigation to prevent the spread of 2019 nCOV $[14,15]$. Therefore, this study intends to concentrate on studying the new corona virus in Saudi Arabia.

\section{Methodology}

This is a descriptive study of 10 Saudi students that were evacuated by royal order from Wuhan city on the 2nd of February 2020. Upon arrival the students were assessed medically in the airport and their COVID-19 swabs were taken. Then they were sent directly to a separate housing building in a medical facility under the umbrella of the ministry of health, where they were quarantined to observe for symptoms for 14 days consecutively. The housing was prepared for them, each in an individual suite, with highest allergy nor history of blood transfusion. standards of comfort and a feeling of home. With a gaming play area and surrounding private gardens. Their needs were all filled from basic needs such as clothes and food, to more luxurious needs like playing cards and playstations, sim cards, internet, laptops.... etc. They were educated on proper hand hygiene and proper personal protection. Students were assessed by medical Physicians on first arrival and background medical history was taken. An initial psychological assessment was done by a team of psychiatrists and psychotherapists. Later, they were monitored daily for vital signs, and symptoms of disease and a daily psychological assessment was done. All the above data was documented in patient medical records, we extracted the data and analyzed it uses Microsoft Excel Software V.15.35, for data analysis. All the students were consented prior to this study.

\section{Data Analysis and Results}

Males represent $(100 \%)$ of the total number of the patients sampled in this study, with a mean age of 25-year-old (Graph 1). All the patients are classified as middle aged, and all of them are smokers. Regarding the duration in China, all the patients have been trapped for 20 days in Wuhan prior to evacuation, and there is no contact with positive COVID-19 cases. Furthermore, the past medical history was unremarkable. There is no history of known

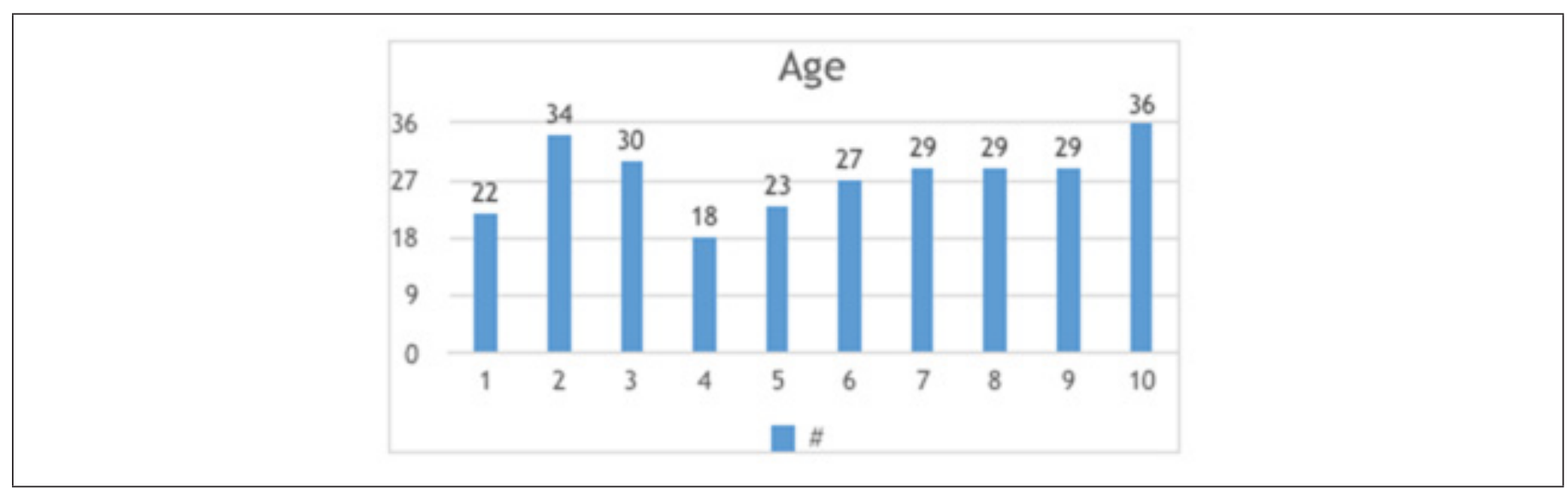

\section{Graph 1: Age of patients.}

In daily clinical assessment of the vital signs which include: (temperature, oxygen saturation, blood pressure, pulse rate and respiratory rate) and other lab tests, data showed that the ten patients through 14 days had unremarkable results and were medically fit.

Their average temperature in the 14 days of Quarantine is shown in Table 1 was between (36.3-36.6). The Maximum temperature for all patients in 14 days was between (36.5-37.2), patient number ten again has ranked first in the maximum temperature in 14 days (37.2). (Graph 2). The average Respiratory Rate for all patients in 14 days was between (16.5-17.8) (Table 2). The maximum Respiratory Rate

for all patients in 14 days was between (18-24), patients' number eight ranked first in the maximum Respiratory Rate value in 14 days (24) (Graph 3). The average oxygen saturation for all patients in 14 days was between (98\%-99.5\%) (Graph 4). The minimum oxygen saturation for all patients in 14 days was between (90\%-98\%), the results shows that the patient nine ranked last in the minimum oxygen saturation value in 14 days(90\%), and the patients six and seven ranked first in the minimum oxygen saturation value in 14 days(98\%) (Graph 5). The average Pulse rate for all patients in 14 days was between (78-96). While the maximum Pulse rate for all patients in 14 days was between (120-100), the patient number 
six had the highest Pulse rate value in 14 days (120) (Table 3). The average blood pressure for all patients in 14 days was between (114/72-128/78), the results showed that the patient number four was negative for all the patients.

Table 1: Average Temperature for patients in 14 days

\begin{tabular}{|c|c|}
\hline Patients & Avg Temp \\
\hline 1 & 36.4 \\
\hline 2 & 36.3 \\
\hline 3 & 36.5 \\
\hline 4 & 36.5 \\
\hline 5 & 36.3 \\
\hline 6 & 36.3 \\
\hline 7 & 36.4 \\
\hline 8 & 36.5 \\
\hline 9 & 36.5 \\
\hline 10 & 36.6 \\
\hline
\end{tabular}

Table 2: Average Respiratory Rate for patients in 14 days

\begin{tabular}{|c|c|}
\hline Patients & Average Respiratory \\
\hline 1 & 17 \\
\hline 2 & 16.5 \\
\hline 3 & 17.5 \\
\hline 4 & 17 \\
\hline 5 & 17 \\
\hline 6 & 16.9 \\
\hline 7 & 17.2 \\
\hline 8 & 16.7 \\
\hline 9 & 17.4 \\
\hline 10 & 17.8 \\
\hline
\end{tabular}

Table 3: Maximum Pulse rate for patients in 14 days

\begin{tabular}{|c|c|}
\hline Patients & Max Pulse Rate \\
\hline 1 & 110 \\
\hline 2 & 110 \\
\hline 3 & 100 \\
\hline 4 & 100 \\
\hline 5 & 100 \\
\hline 6 & 120 \\
\hline 7 & 100 \\
\hline 8 & 114 \\
\hline 9 & 110 \\
\hline 10 & 100 \\
\hline
\end{tabular}

Table 4: Average Blood Pressure for patients in 14 days

\begin{tabular}{|c|c|c|}
\hline Patients & Systolic & Diastolic \\
\hline 1 & 121 & 74 \\
\hline 2 & 119 & 67 \\
\hline
\end{tabular}

has the minimum average blood pressure in 14 days (114/72), and the patient number ten has the maximum one in 14 days(128/78). (Table 4). According to the pathology report the sputum sample 


\begin{tabular}{|l|l|l|}
\hline 3 & 120 & 71 \\
\hline 4 & 114 & 72 \\
\hline 5 & 122 & 74 \\
\hline 6 & 124 & 70 \\
\hline 7 & 120 & 74 \\
\hline 8 & 118 & 80 \\
\hline 9 & 118 & 76 \\
\hline 10 & 128 & 78 \\
\hline
\end{tabular}

Table 5: Psychological assessment

\begin{tabular}{|c|c|c|c|c|}
\hline Patient No. & Psychosocial Assessment: 1 & Psychosocial Assessment: $\mathbf{2}$ & Psychosocial Assessment: $\mathbf{3}$ & Psychosocial Assessment: 4 \\
\hline 1 & Healthcare has been given & Needs an assessment & Request to visit his family & Request to visit his family \\
\hline 2 & Needs an assessment & Reassess his situation & Request to see his family & Request to see his family \\
\hline 3 & Healthcare has been given & Stable & request to visit his family & Request to see his family \\
\hline 4 & Stable & Doesn't need anything & Need family visit & Request to see his family \\
\hline 5 & Healthcare has been given & Stable & Request family visit & Stable \\
\hline 6 & Healthcare has been given & Needs further follow-up & Request family visit & Request family visit \\
\hline 7 & Needs an Assessment & Stable & Request family visit & Request family visit \\
\hline 8 & Healthcare has been given & Stable & Request family visit & Stable \\
\hline 9 & Needs an assessment & $\begin{array}{c}\text { Provide him with special } \\
\text { requests }\end{array}$ & Request to visit a friend & Request to visit his family \\
\hline 10 & Nl & Nl & Nl & Nl \\
\hline
\end{tabular}

\begin{tabular}{|c|c|c|c|c|c|}
\hline$\#$ & Psychosocial Assessment: 5 & Psychosocial Assessment: 6 & $\begin{array}{l}\text { Psychosocial Assess- } \\
\text { ment: } 7\end{array}$ & $\begin{array}{l}\text { Psychosocial Assess- } \\
\text { ment: } 8\end{array}$ & $\begin{array}{l}\text { Psychosocial Assess- } \\
\text { ment: } 9\end{array}$ \\
\hline 1 & Request to visit his family & Request to visit his family & Family visited him & $\begin{array}{l}\text { Comfortable waiting for } \\
\text { discharge home }\end{array}$ & $\begin{array}{l}\text { Comfortable waiting } \\
\text { for discharge home }\end{array}$ \\
\hline 2 & Request to visit his family & Family visited & $\begin{array}{l}\text { Comfortable waiting for } \\
\text { discharge home }\end{array}$ & $\begin{array}{l}\text { Comfortable waiting for } \\
\text { discharge home }\end{array}$ & $\begin{array}{l}\text { Comfortable waiting } \\
\text { for discharge home }\end{array}$ \\
\hline 3 & Request to visit his family & Request to visit his family & Stable & Family visited him & $\begin{array}{l}\text { Comfortable waiting } \\
\text { for discharge home }\end{array}$ \\
\hline 4 & Request to visit his family & Angry wants to leave & Request to visit his family & $\begin{array}{l}\text { Request to visit his } \\
\text { family }\end{array}$ & Family visited him \\
\hline 5 & Request to visit his family & Request to visit his family & Request to visit his family & $\begin{array}{l}\text { Request to visit his } \\
\text { family }\end{array}$ & $\begin{array}{l}\text { Request to visit his } \\
\text { family }\end{array}$ \\
\hline 6 & Request to visit his family & Request to visit his family & Request to visit his family & Family visited him & $\begin{array}{l}\text { Comfortable waiting } \\
\text { for discharge home }\end{array}$ \\
\hline 7 & Request to visit his family & Request to visit his family & Request to visit his family & $\begin{array}{l}\text { Request to visit his } \\
\text { family }\end{array}$ & Family visited him \\
\hline 8 & Request to visit his family & Request to visit his family & Angry want to go home & Family visited him & $\begin{array}{l}\text { Angry want to go } \\
\text { home }\end{array}$ \\
\hline 9 & Request to visit his family & Request to visit his family & Request to visit his family & $\begin{array}{l}\text { Request to visit his } \\
\text { family }\end{array}$ & $\begin{array}{l}\text { Angry want to go } \\
\text { home }\end{array}$ \\
\hline 10 & $\mathrm{Nl}$ & $\mathrm{Nl}$ & $\mathrm{Nl}$ & $\mathrm{Nl}$ & $\mathrm{Nl}$ \\
\hline
\end{tabular}

\begin{tabular}{|c|c|c|c|c|c|}
\hline$\#$ & $\begin{array}{c}\text { Psychosocial Assessment: } \\
\mathbf{1 0}\end{array}$ & $\begin{array}{c}\text { Psychosocial Assessment: } \\
\mathbf{1 1}\end{array}$ & $\begin{array}{c}\text { Psychosocial Assess- } \\
\text { ment: 12 }\end{array}$ & $\begin{array}{c}\text { Psychosocial Assess- } \\
\text { ment: 13 }\end{array}$ & $\begin{array}{c}\text { Psychosocial Assess- } \\
\text { ment: 14 }\end{array}$ \\
\hline 1 & Request to visit his family & Request to visit his family & Request to visit his family & $\begin{array}{c}\text { Comfortable waiting for } \\
\text { discharge home }\end{array}$ & $\begin{array}{c}\text { Comfortable waiting for } \\
\text { discharge home }\end{array}$ \\
\hline 2 & Family visit again & $\begin{array}{c}\text { Comfortable waiting for } \\
\text { discharge home }\end{array}$ & Fine & Doing well & $\begin{array}{c}\text { Comfortable waiting for } \\
\text { discharge home }\end{array}$ \\
\hline 3 & $\begin{array}{c}\text { Comfortable waiting for } \\
\text { discharge home }\end{array}$ & $\begin{array}{c}\text { Comfortable waiting for } \\
\text { discharge home }\end{array}$ & $\begin{array}{c}\text { Comfortable waiting for } \\
\text { discharge home }\end{array}$ & $\begin{array}{c}\text { Comfortable waiting for } \\
\text { discharge home }\end{array}$ & $\begin{array}{c}\text { Comfortable waiting for } \\
\text { discharge home }\end{array}$ \\
\hline
\end{tabular}




\begin{tabular}{|c|c|c|c|c|c|}
\hline 4 & Angry want to leave & Angry wants to leave & Angry wants to go home & Angry wants to go home & Angry wants to go home \\
\hline 5 & Family visit again & $\begin{array}{c}\text { Comfortable waiting for } \\
\text { discharge home }\end{array}$ & $\begin{array}{c}\text { Comfortable waiting for } \\
\text { discharge home }\end{array}$ & $\begin{array}{c}\text { Comfortable waiting for } \\
\text { discharge home }\end{array}$ & Asking when to go home \\
\hline 6 & $\begin{array}{c}\text { Comfortable waiting for } \\
\text { discharge home }\end{array}$ & $\begin{array}{c}\text { Comfortable waiting for } \\
\text { discharge home }\end{array}$ & $\begin{array}{c}\text { Irritable waiting to go } \\
\text { home }\end{array}$ & $\begin{array}{c}\text { Irritable waiting to go } \\
\text { home }\end{array}$ & $\begin{array}{c}\text { Irritable waiting to go } \\
\text { home }\end{array}$ \\
\hline 7 & $\begin{array}{c}\text { Irritable waiting to go } \\
\text { home }\end{array}$ & $\begin{array}{c}\text { Irritable waiting to go } \\
\text { home }\end{array}$ & $\begin{array}{c}\text { Irritable waiting to go } \\
\text { home }\end{array}$ & $\begin{array}{c}\text { Irritable waiting to go } \\
\text { home }\end{array}$ & $\begin{array}{c}\text { Irritable waiting to go } \\
\text { home }\end{array}$ \\
\hline 8 & Angry want to go home & Angry want to go home & Angry want to go home & Angry want to go home & $\begin{array}{c}\text { Threatening to run away if } \\
\text { not sent home }\end{array}$ \\
\hline 9 & Angry want to go home & Family visited him & Angry want to go home & Angry want to go home & Angry wants to go home \\
\hline 10 & $\mathrm{Nl}$ & $\mathrm{Nl}$ & $\mathrm{Nl}$ & Nl & $\mathrm{Nl}$ \\
\hline
\end{tabular}

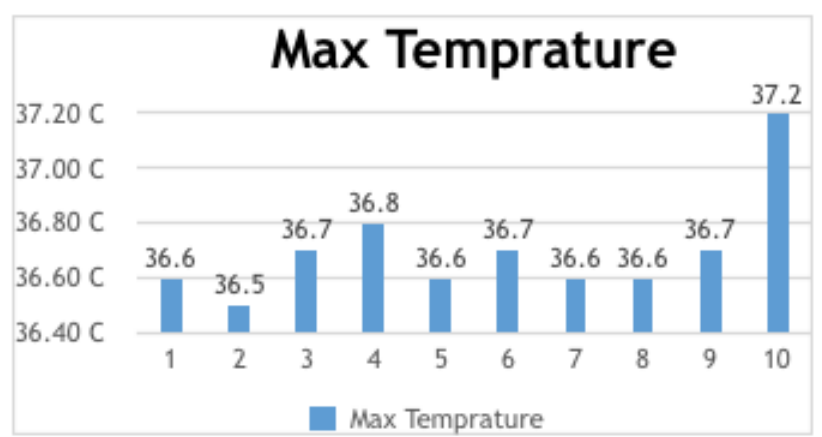

Graph 2: Maximum Temperature in 14 days.

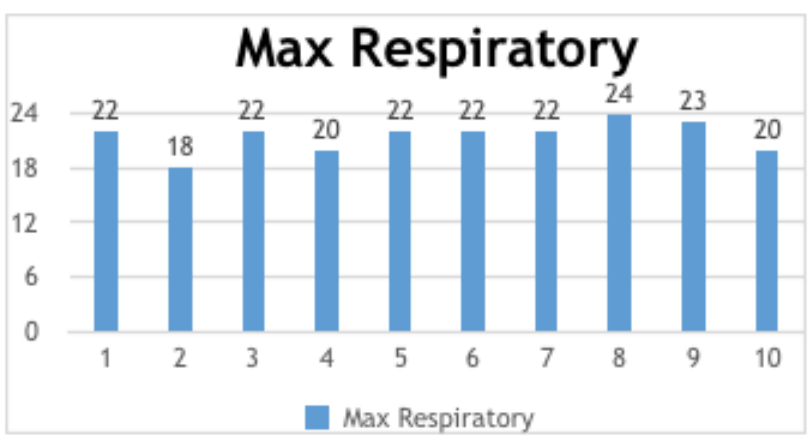

Graph 3: Maximum Respiratory Rate for patients in 14 days.

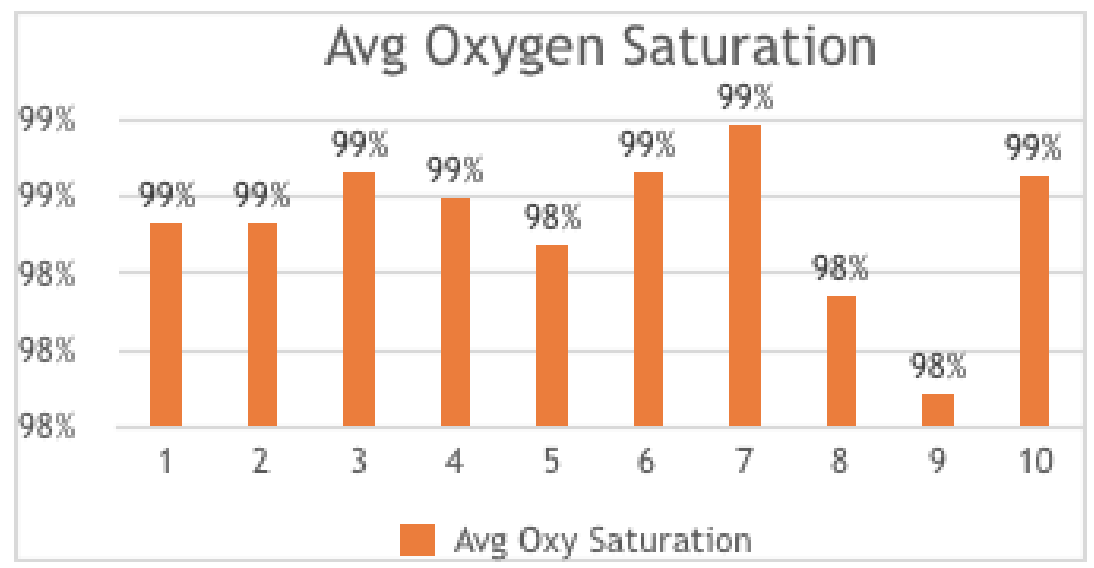

Graph 4: Average oxygen saturation for patients in 14 days. 


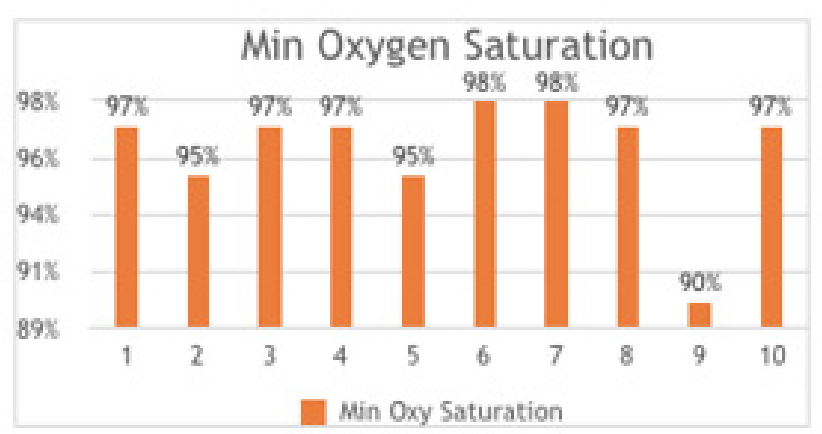

Graph 5: Minimum oxygen Saturation for patients in 14 days.

Table 5 shows the psychosocial assessment for the patients in 14 days, it shows that the patient number one, takes the healthcare required on the first day, and he needs assessment on the second day, on the third, fourth, fifth, sixth day he requests to visit his family. On the seventh day his family visited him, and the eighth and ninth day he was comfortable and waiting for discharge, for the next three days he was asking to see his family. For the last three days, he was comfortable and waiting for discharge.

The patient number two needs an assessment on the first day, and he needs to reassess his situation on the second day, on the third, fourth and fifth day he requests to visit his family. On the sixth day his family visited him, and the seventh, eighth, and ninth he was comfortable and waiting for discharge. On the tenth day, his family visited him again, and for the last days he was fine, doing well, and comfortable waiting for discharge.

The patient number three takes the healthcare required on the first day, and he needs to reassess his situation on the second day, on the third, fourth, fifth, sixth day he requested to see his family. The patient was psychologically stable on the seventh day because he was informed that his family will visit him on the next day. From day 9 to day 14, the patient was stable waiting to be discharged.

The patient number four was stable on the first day, and he did not need anything on the second day. on the third, fourth, and fifth day he requested to see his family. On the sixth day, the patient got angered and was asking for his family to visit him till they visited him on a ninth day. from day 10 till day 14, he was impulsive and angry, demanding to be discharged and go home.

The patient number five takes the healthcare required on the first day, his situation was stable on the second day, on the third until the ninth day he requests to visit his family, and he was stable. On the tenth day, his family visited him, and he was comfortable and waiting for discharge in the next three days, and on the last day, he was asking when to go home.

The patient number six takes the healthcare required on the first day, and he needs further follow-up on the second day, on the third to the seventh day he requests to visit his family. On the eighth day, his family visited him, and he was comfortable waiting for discharge for the next three days. On the last three days, he was irritable waiting to go home.

The patient number seven needs an assessment on the first day, and he was stable on the second day, on the third till the eighth day he requests to visit his family. On the ninth day, his family visited him, and for the last five days, he was irritable waiting to go home.

The patient number eight took his healthcare required on the first day, and he was stable on the second day, on the third day he requested to see his family and he was stable on the fourth day. The patient was requesting to see his family while he was in a stable psychological state till day 6 . The patient's family visited him on the eighth day, and he got stable. From day 9 till day 14, the patient was angry and wanted to be discharged. Furthermore, he threatened to leave the hospital on the last day.

The patient number nine needs an assessment on the first day, and we provide him with special requests on the second day. From the third till the eighth day he requested to visit his family, and he was angry wanting to go home from the ninth day till the last day.

Regarding patient number ten, he did not go under the psychological assessment because he was transferred to a tertiary hospital.

\section{Discussion}

The students were all male adults, medically fit, healthy, and did not complain of any previous, recent, nor chronic medical complaint. Their COVID-19 swabs were taken from them since they arrived and came out negative for all of them, and this can be due to them having no contact with positive cases and the short period that they were in Wuhan, China.

For their vital signs and clinical assessment, they were assessed twice a day, day by day in the 14 days and they were stable, feeling well, and their vitals were normal throughout their stay, except one of them in the first day was having runny nose and low grade fever, 
but he got better the next day. No complications were documented, throughout their quarantine.

The students psychological status was fluctuating, starting with fear and uncertainty in the beginning, which can be explained by them being trapped in an empty city for 20 days, and the uncertainty of their health conditions, with days they started to relax after being welcomed and treated with luxury and finally reaching their home land. Within days, the effect of being trapped in quarantine made some of them restless which led them to develop some bouts of anger, and they expressed some feelings of missing their families and friends. When the family visits started by day 7 most of the students relaxed and were at ease and were waiting eagerly for day 14 to be sent home. They were discharged safely after day 14 .

From the psychological impact aspect, it was taken in mind from the first day trying to comfort them and preventing exacerbation of the situation by influencing simple explanations of the recent situation and convincing them to stay relaxed. Meanwhile they were encouraged to do some exercises and achieve self-satisfaction by involvement in certain activities and hobbies such as play cards games, play station, and having unlimited access on the internet etc. Also, their requests and special needs were fulfilled for them to make them feel comfortable while they were in quarantine. Furthermore, daily assessment of psychosocial effect was mandatory scheduled to prevent any short-term or even long-term complications driven by psychosocial impact.

In our study we strongly suggest that the first concern in the assessment process of a suspected-to-be infected individual should be the continuous assessment of his/her psychological state. Taking a detailed psychiatric history along with full examination of the mental state for the individuals who are known to be cases of certain psychiatric disorders especially those with anxiety or depression would be highly effective in the whole medical management. Moreover, it has been estimated that the impact of COVID-19 had led the population to express negative emotions for self-protection.

As the COVID-19 pandemic plows over the world, it results in a widespread of concern, fear, and stress, they are normal reactions to the sudden changes and the uncertain situation that everyone finds themselves in. Mental health care and psychosocial support are crucial in this situation which the whole world is facing. The strong, intensive, and empathic orientation by the media and governments across the world toward the population in order to aware them of the sudden necessary and important use of the sterilizers and facial masks, and also to check for their temperature degrees, symptoms, recommendations to stay at home, and the social distancing, each of which has increased the risk for developing certain mental and psychological issues among the population in every age group, especially the children.
Children are facing a tremendous perturbation to their lives. They are likely to experience anxiety and fear like those experienced by adults such as fear of dying and fear of medical management. Furthermore, children have been instructed to stay at their homes because the schools are closed to decrease the likelihood of the viral infection to be spread between them, this resulted in children not being with their friends which may affect their mental health well-being. Staying at home may expose the children to protection incidents or they may witness some interpersonal violence if their home is not a safe place. Children have sensitive insight and are perceptive to change, and they may find the changing happening nowadays are difficult to be understood which may lead them to develop irritable, and angry behavior. This may result in parents and caregivers to go under challenging time and extreme pressure trying to resolve these issues which children are experiencing. By providing love and attention to children and young adults, this can help in minimizing and resolving their fear and anxiety. Explaining the situation of the pandemic issue in a simple method will lead the children to be aware of it. Helping and encouraging the children to do daily activities will help them to resemble the routine that they used to practice at schools. Moreover, providing support to parents in order to relieve their stress will be beneficial.

On the other hand, regarding elderly people and those with comorbidities and chronic diseases who are more likely to be infected with COVID-19, they will be extremely anxious, afraid, and angry. This impact could be more difficult for them especially if they suffer cognitive decline or dementia. Also, some older people may already be socially isolated or experiencing loneliness which may exacerbate and worsen their mental health. Going under regular physical activities, keeping and creating routines, engaging with certain activities that give the sense of achievement and selfsatisfaction will help in maintaining good mental health for this age group.

\section{Conclusion}

Mental health is crucial for all age groups and providing support for the population in order to help them bearing these situations which require strict instructions that may change the way of their life suddenly is more important. Cooperation between health associations in order to develop courses, workshops, or online lectures will be an excellent approach to raise the level of awareness of the population to deal with such pandemic issues under any circumstances.

\section{Funding}

This research received no external funding.

\section{Conflicts of Interest}

The authors declare no conflict of interest. 


\section{References}

1. de Groot R. J, SC Baker, RS Baric, CS Brown, C Drosten, et al. (2013) Middle East Respiratory Syndrome Coronavirus (MERS-Cov): Announcement of The Coronavirus Study Group. J Virol 87(14): 7790-7792.

2. (2020) Clinical Management of Severe Acute Respiratory Infection When Middle East Respiratory Syndrome Coronavirus (MERS-Cov) Infection Is Suspected. World Health Organization.

3. Yin Yudong, Richard G Wunderink (2017) MERS, SARS And Other Coronaviruses As Causes Of Pneumonia. Respirology 23(2): 130-137.

4. Pyrc Krzysztof, Ben Berkhout, Lia van der Hoek (2007) Identification Of New Human Coronaviruses. Expert Rev Anti Infect Ther 5(2): 245-253.

5. Xu, Xintian, Ping Chen, Jingfang Wang, Jiannan Feng, et al. (2020) Evolution of The Novel Coronavirus from The Ongoing Wuhan Outbreak and Modeling Of Its Spike Protein for Risk of Human Transmission. Sci China Life Sci 63(3): 457-460.

6. Osterhaus A D M E, R A M Fouchier, T Kuiken (2004) The Aetiology Of SARS: Koch's Postulates Fulfilled. Philos Trans R Soc Lond B Biol Sci 359(1447): 1081-1082.

7. Lambert, Stephen, Ian M Mackay, Theo P Sloots, Michael D Nissen (2006) Human Coronavirus Nomenclature. Pediatr Infect Dis J 25(7): 662.

8. Habibzadeh, Parham, Emily K Stoneman (2020) The Novel Coronavirus: A Bird's Eye View. Int J Occup Environ Med 11(2): 65-71.

9. (2020) Coronavirus Disease (COVID-19): Outbreak Update - Canada.Ca.

10. Lu Hongzhou, Charles W Stratton, Yi Wei Tang (2020) Outbreak of Pneumonia Of Unknown Etiology In Wuhan, China: The Mystery And The Miracle. J Med Virol 92(4): 401-402.

11. (2020) Novel Coronavirus - Japan (Ex-China). World Health Organization.

12. Zhang Liangsheng, Fu ming Shen, Fei Chen, Zhenguo Lin (2020) Origin and Evolution of the 2019 Novel Coronavirus. Clin Infect Dis 71(15): 882-883.

13. (2020) Coronavirus Disease 19 (COVID-19) Guidelines February 2020 V1.1. Moh Gov Sa.

14. Huang Chaolin, Yeming Wang, Xingwang Li, Lili Ren, Jianping Zhao et al. (2020) Clinical Features of Patients Infected With 2019 Novel Coronavirus in Wuhan, China. The Lancet 395(10223): 497-506.

15. Wang Dawei, Bo Hu, Chang Hu, Fangfang Zhu, Xing Liu, et al. (2020) Clinical Characteristics Of 138 Hospitalized Patients With 2019 Novel
Coronavirus-Infected Pneumonia in Wuhan, China. JAMA 323(11): 1061-1069.

16. Mackenzie John S, David W Smith (2020) COVID-19: A Novel Zoonotic Disease Caused by A Coronavirus from China: What We Know and What We Don't. Microbiol Aust MA20013.

17. Arentz Matt, Eric Yim, Lindy Klaff, Sharukh Lokhandwala, Francis X Riedo, et al. (2020) Characteristics and Outcomes Of 21 Critically Ill Patients With COVID-19 In Washington State. JAMA 323(16): 16121614.

18. (1975) ACEP News. Journal Of The American College Of Emergency Physicians 4(1): 75-80.

19. (2020) We'Re Still Not Sure Where the Novel Coronavirus Really Came From. Popular Science.

20. Molteni Megan (2020) No, The Wuhan Virus Is Not A 'Snake Flu'. Wired.

21. Chen Nanshan, Min Zhou, Xuan Dong, Jieming Qu, Fengyun Gong, et al. (2020) Epidemiological and Clinical Characteristics Of 99 Cases Of 2019 Novel Coronavirus Pneumonia in Wuhan, China: A Descriptive Study. The Lancet 395(10223): 507-513.

22. Hui David S, Esam I Azhar, Tariq A Madani, Francine Ntoumi, Richard Kock, et al. (2020) The Continuing 2019-Ncov Epidemic Threat Of Novel Coronaviruses To Global Health-The Latest 2019 Novel Coronavirus Outbreak In Wuhan, China". Int J Of Infect Dis 91: 264-266.

23. Holshue Michelle L, Chas DeBolt, Scott Lindquist, Kathy H Lofy, John Wiesman, et al. (2020) First Case Of 2019 Novel Coronavirus In The United States. N Eng J Med 382(10): 929-936.

24. (2020) Statement on the Second Meeting of The International Health Regulations (2005) Emergency Committee Regarding the Outbreak Of Novel Coronavirus (2019-Ncov). Who Int.

25. Zhu Na, Dingyu Zhang, Wenling Wang, Xingwang Li, Bo Yang, et al. (2020) A Novel Coronavirus From Patients With Pneumonia In China, 2019. N Engl J Med 382(8): 727-733.

26. Lu Roujian, Xiang Zhao, Juan Li, Peihua Niu, Bo Yang, et al. (2020) Genomic Characterisation And Epidemiology Of 2019 Novel Coronavirus: Implications For Virus Origins And Receptor Binding. The Lancet 395(10224): 565-574.

27. Chu Daniel K W, Yang Pan, Samuel M S Cheng, Kenrie P Y Hui, Pavithra Krishnan, et al. (2020) Molecular Diagnosis Of A Novel Coronavirus (2019-Ncov) Causing An Outbreak Of Pneumonia. Clin Chem 66(4): 549-555. 